\title{
Hypoxia regulates FGFR3 expression via HIF-1 $\alpha$ and miR-100 and contributes to cell survival in non-muscle invasive bladder cancer
}

\author{
C Blick ${ }^{1}$, A Ramachandran ${ }^{1,2}$, S Wigfield ${ }^{1}$, R McCormick$^{1}$, A Jubb ${ }^{1}$, F M Buffa ${ }^{1}$, H Turley $^{1}$, \\ M A Knowles ${ }^{3}$, D Cranston ${ }^{4}$, J Catto ${ }^{5}$ and A L Harris ${ }^{\star, 1}$ \\ ${ }^{1}$ Molecular Oncology Laboratories, The Weatherall Institute of Molecular Medicine, The University of Oxford, John Raddliffe Hospital, \\ OX3 9DS Oxford, UK; ${ }^{2}$ Cancer Research UK London Research Institute, Lincoln's Inn Fields Laboratories, London, UK; ${ }^{3}$ Section of \\ Experimental Oncology, Leeds Institute of Molecular Medicine, Leeds, UK; ${ }^{4}$ Department of Urology, The Churchill Hospital, Oxford, \\ UK and ${ }^{5}$ The Academic Department of Urology and Institute for Cancer Studies, University of Sheffield, Sheffield, UK
}

Background: Non-muscle invasive (NMI) bladder cancer is characterised by increased expression and activating mutations of FGFR3. We have previously investigated the role of microRNAs in bladder cancer and have shown that FGFR3 is a target of miR-100. In this study, we investigated the effects of hypoxia on miR-100 and FGFR3 expression, and the link between miR-100 and FGFR3 in hypoxia.

Methods: Bladder cancer cell lines were exposed to normoxic or hypoxic conditions and examined for the expression of FGFR3 by quantitative PCR (qPCR) and western blotting, and miR-100 by qPCR. The effect of FGFR3 and miR-100 on cell viability in twodimensional (2-D) and three-dimensional (3-D) was examined by transfecting siRNA or mimic-100, respectively.

Results: In NMI bladder cancer cell lines, FGFR3 expression was induced by hypoxia in a transcriptional and HIF-1 $\alpha$-dependent manner. Increased FGFR3 was also in part dependent on miR-100 levels, which decreased in hypoxia. Knockdown of FGFR3 led to a decrease in phosphorylation of the downstream kinases mitogen-activated protein kinase (MAPK) and protein kinase B (PKB), which was more pronounced under hypoxic conditions. Furthermore, transfection of mimic-100 also decreased phosphorylation of MAPK and PKB. Finally, knocking down FGFR3 profoundly decreased 2-D and 3-D cell growth, whereas introduction of mimic-100 decreased 3-D growth of cells.

Conclusion: Hypoxia, in part via suppression of miR-100, induces FGFR3 expression in bladder cancer, both of which have an important role in maintaining cell viability under conditions of stress.

Bladder cancer is the 9 th most prevalent cancer in the world (Ploeg et al, 2009). In the United Kingdom, there are $\sim 10000$ new cases of bladder cancer diagnosed each year. The majority (90\%) of cases of bladder cancer are derived from the urothelium and are termed urothelial cancers (UC; Luis et al, 2007; Office for National Statistics, 2009). There are two subtypes of UC (Wu, 2005; McConkey et al, 2010). Around 20\% of patients present with muscle invasive (MI) cancer associated with higher mortality (McConkey et al, 2010). However, the majority of patients
(70-80\%) are diagnosed with low-grade non-muscle invasive (NMI) disease. The NMI cancer is associated with a low incidence of progression but a high recurrence rate (McConkey et al, 2010; Pollard et al, 2010). Thus, although not fatal, NMI cancer requires long-term monitoring of patients and regular surveillance, making this the most expensive cancer per patient to manage.

The two subtypes of UC have distinct underlying aetiologies. The MI cancer is associated with inactivating mutations in the TP53, RB and PTEN genes (Castillo-Martin et al, 2010; Goebell and 
Knowles, 2010). In contrast, NMI cancer is characterised by increased expression and activating mutations of FGFR3, H-RAS and phosphotidylinositol-3-kinase (PI3K; Castillo-Martin et al, 2010; Pollard et al, 2010). FGFR3 in particular has an important role in the pathogenesis of bladder cancer, either by mutation in NMI cancer or by increased expression in invasive bladder cancer (Tomlinson et al, 2007). It is one of four members of the FGFR family of receptor tyrosine kinases that serve as cell surface receptors for the FGF ligands. Signalling by the FGFRs leads to the activation of multiple intracellular signalling pathways including the extracellular signalling-regulated kinase/mitogen-activated protein kinase (ERK/MAPK) cascade and PI3K signalling (L'Hote and Knowles, 2005). Germline gain-of-function mutations in FGFR3 that either allow the receptor to signal in the absence of ligand or enhance signalling upon ligand stimulation are associated with achondroplasia and hypochondroplasia (L'Hote and Knowles, 2005). On the other hand, germline loss-of-function mutations have been associated with CATSHL syndrome and characterised by tall stature and loss of hearing (Toydemir et al, 2006). In addition to bladder cancer, FGFR3 mutations have also been identified in myeloma (Foldynova-Trantirkova et al, 2012) and cervical cancer (Dai et al, 2001), with aberrant fusion proteins being described in glioblastoma multiforme (Singh et al, 2012). Small molecule inhibitors (Lamont et al, 2011) and blocking antibodies (Martinez-Torrecuadrada et al, 2005) against FGFR3 inhibit the growth of bladder cancer cell lines in vitro and xenografts in vivo.

Hypoxia is a key feature of many solid tumours including bladder cancer (Turner et al, 2002; Ioachim et al, 2006; Ord et al, 2007; Chai et al, 2008; Tickoo et al, 2011). The cellular effects of hypoxia are primarily mediated by hypoxia inducible factor (HIF), a heterodimer of one of two possible $\alpha$-subunits (HIF- $1 \alpha$ or HIF- $2 \alpha$ ) and a $\beta$-subunit. In normoxia, the $\alpha$-subunits are hydroxylated by prolyl hydroxylases (PHDs), which targets them for ubiquitination and degradation. In hypoxia, the activity of the PHDs is inhibited, leading to the stabilisation of the $\alpha$-subunit and its dimerisation with the $\beta$-subunit. The HIF transcription factor binds to HIF response elements (HREs) on DNA to drive the expression of target genes that regulate diverse biological processes including angiogenesis (VEGF), metabolism (LDHA) and invasion (LOX; Brahimi-Horn and Pouyssegur, 2009).

An emerging class of molecules whose expression is regulated by hypoxia are microRNAs (miRNAs). MicroRNAs are small, singlestranded RNA molecules that bind with imperfect complementarity to the $3^{\prime}$ untranslated region (UTR) of target genes and primarily suppress the translation of the cognate protein (Pillai et al, 2007). By expression profiling, we have previously identified a number of miRNAs differentially regulated in distinct UC subtypes (Catto et al, 2009). It has also been shown that miRNA expression may predict tumour grade and therefore recurrence or progression (Gottardo et al, 2007; Catto et al, 2009; Neely et al, 2010).

Although FGFR3 can be mutated or overexpressed in UC, the mechanisms underlying altered FGFR3 expression in NMI bladder cancer are not well understood. We have previously shown that miR-100 is downregulated in NMI bladder cancer and that this may be responsible for increased FGFR3 expression (Catto et al, 2009). In this study, we investigated the effect of hypoxia on regulating the expression of FGFR3 and uncovered a role for both HIF- $1 \alpha$ and miR-100 in regulating FGFR3 levels and downstream signalling pathways.

\section{MATERIALS AND METHODS}

Cell culture. Cell lines RT4, RT112 and T24 were obtained from Cancer Research UK Cell Services (Clare Hall Laboratories, London, UK). The 97-7 mutant S249C FGFR3 cell line was obtained from Margaret Knowles, The University of Leeds, UK. Cell lines were grown in appropriate media, containing antibiotics, with supplemental material from Sigma-Aldrich (Dorset, UK). Exposure of cell cultures to hypoxia ( $1 \%$ or $0.1 \%$ oxygen $\left.\left(\mathrm{O}_{2}\right)\right)$ was undertaken in a hypoxia incubator (MiniGalaxy A, RS Biotech, Scotland, UK) or in a hypoxic workstation (In $\mathrm{Vivo}_{2}$, Ruskinn Technology, Bridgend, UK) in parallel with cells maintained in normoxic conditions $\left(5 \% \mathrm{CO}_{2}, 37^{\circ} \mathrm{C}, 21 \% \mathrm{O}_{2}\right)$.

RNA extraction. Cells were lysed with Tri Reagent (Sigma-Aldrich) and extracted using chloroform, followed by ethanol precipitation. RNA quality and quantity were confirmed using the NanoDrop ND1000 spectrophotometer (Thermo Scientific, Waltham, MA, USA).

Reverse transcription and qPCR for miRNAs. Hsa-miRNA expression was assessed by real-time PCR according to the TaqMan MicroRNA Assay protocol (Applied Biosystems, Warrington, UK). The cDNA was synthesised from $350 \mathrm{ng}$ of total RNA using either TaqMan miRNA-specific primers and the TaqMan MicroRNA Reverse Transcription Kit or TaqMan Megaplex Primer Pool A, together with the TaqMan Reverse Transcription Kit. Quantitative real-time PCR was performed on either on the Rotor-Gene 3000 (Corbett Research, Qiagen, West Sussex, UK) or 7900HT Fast Real Time PCR System (Applied Biosystems). For each miRNA, each sample was assayed in triplicate. Fold changes in miR-100 expression between treatments and controls were determined by the 2-DDCt method (Livak and Schmittgen, 2001), normalising the results as appropriate, using some or all of the small nRNAs RNU44 and RNU48.

Reverse transcription and $\mathbf{q P C R}$ for mRNA. Total RNA was reverse transcribed to cDNA using random primers and the High Capacity cDNA Synthesis Kit (Applied Biosystems). The expression of FGFR3 and CAIX along with the internal control gene ACTIN was assayed by quantitative PCR (qPCR) using Sybr Green (Bioline Reagents Ltd, London, UK). Primer sequences are as follows: ACTIN_F: 5'-ATTGGCAATGAGCGGTTC-3', ACTIN_R: 5'-GGA TGCCACAGGACTCCAT- $3^{\prime}$, CAIX_F: $5^{\prime}$-CTTGGAAGAAATC GCTGAGG-3', CAIX_R: 5'-TGGAAGTAGCGGCTGAAGTC-3', FGFR3_F: 5'-GCCTCCTCGGAGTCCTTG-3', FGFR3_R: 5'-CGA AGACCAACTGCTCGTG-3'.

SiRNA/miRNA mimic and anti-miR transfection protocol. Cells were reverse transfected with the Oligofectamine transfection reagent (Invitrogen, Paisley, UK) according the manufacturer's instructions. Briefly, complexes were made in OptiMEM (Invitrogen) with $6 \mu \mathrm{l}$ of oligofectamine and $20 \mathrm{~nm}$ final concentration of siRNA, mimics or anti-miRs. Cells were plated in full media without antibiotics at a density of $3 \times 10^{5}$ cells per $6-\mathrm{cm}$ dish to which the complexes were added. The following day, the media was changed and the cells treated as appropriate. The pooled siGENOME siRNA against FGFR3, pooled siRNA control, miRNA mimics and anti-miRs and appropriate controls were all purchased from Dharmacon (Lafayette, CO, USA). The siRNA sequence against HIF- $1 \alpha$ and HIF- $2 \alpha$ are as follows: siHIF- $1 \alpha$ : $5^{\prime}$-UCAA GUUGCUGGUCAUCAG- $3^{\prime}$, siHIF- $2 \alpha$ : $5^{\prime}$-UAACGACCUGAAG AUUGAA- $3^{\prime}$.

Western blot. Protein lysates were prepared in the urea lysis buffer (6.2 M urea, $5 \mathrm{~mm}$ DTT, $1 \%$ SDS, $10 \%$ glycerol) with added protease (Roche, Indianapolis, IN, USA) and phosphatase (SigmaAldrich) inhibitors. Lysates were quantified using the Bio-Rad Dc System (Bio-Rad, Hertfordshire, UK). Proteins were separated on standard SDS-polyacrylamide gels, transferred onto PVDF membranes and incubated with primary antibodies overnight at $4{ }^{\circ} \mathrm{C}$. Antibodies against FGFR3, phospho-Thr ${ }^{202} / \mathrm{Tyr}^{204}$-MAPK, phospho-Ser ${ }^{473}$-protein kinase B (PKB), total MAPK and total PKB antibodies were all purchased from Cell Signaling Technologies (Danvers, MA, USA). The antibody against ACTIN was purchased 
A
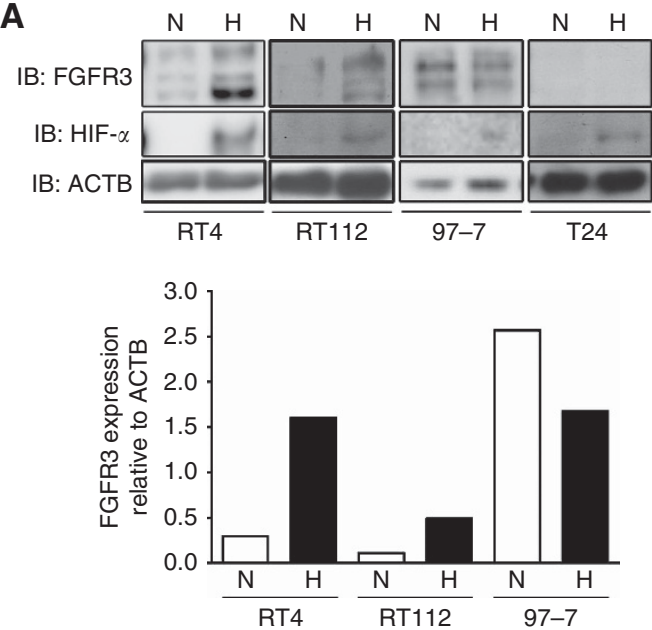

C

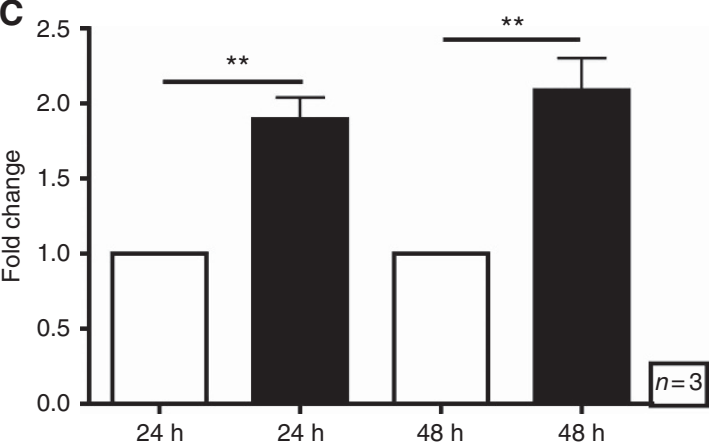

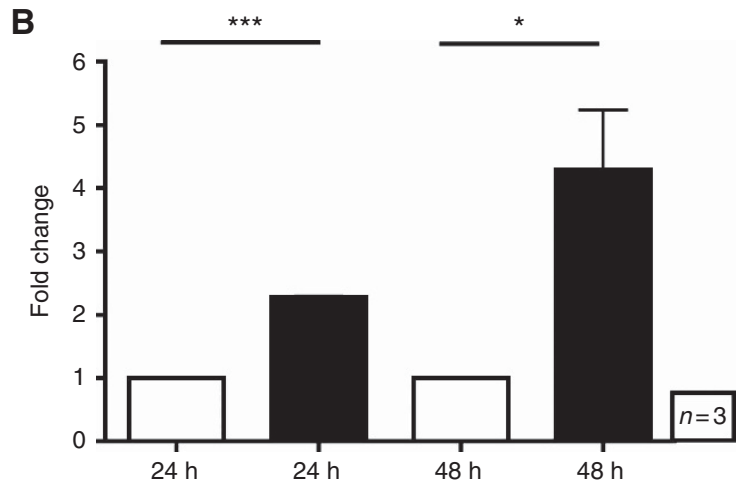

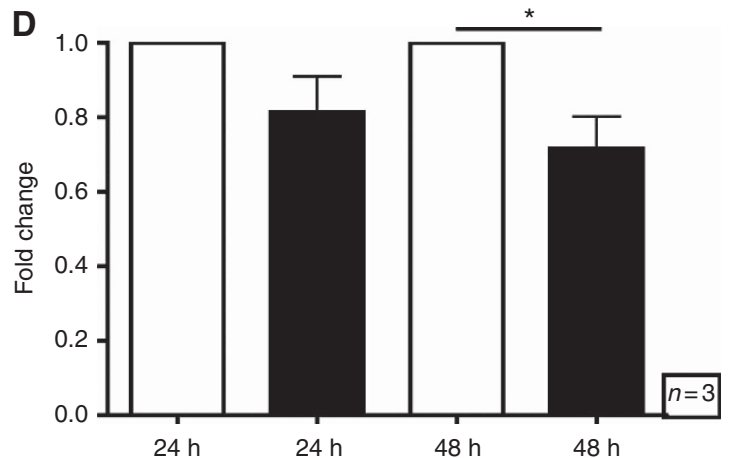

Figure 1. Regulation of FGFR3 expression by hypoxia. (A) Expression of FGFR3 at the protein level in the bladder cancer cell lines RT4, RT112, T24 and 97-7. Cells were cultured in normoxia ( $\mathrm{N}$ ) or $0.1 \% \mathrm{O}_{2}(\mathrm{H})$ for $24 \mathrm{~h}$ and whole cell lysates were probed for FGFR3, HIF- $\alpha$ (RT4 and 97-7: HIF-1 $\alpha$; RT112 and T24: HIF-2 $\alpha$ ) and ACTB. Quantification of representative western blots are shown. (B-D) Expression of FGFR3 mRNA in (B) RT4, (C) RT112 and (D) 97-7 cells after exposure to normoxia (white bars) or $0.1 \% \mathrm{O}_{2}$ (black bars) for the indicated time. (A) is representative of at least three independent experiments, (B-D) are mean and s.e.m. of three independent experiments. ${ }^{\star} P<0.05,{ }^{\star \star} P<0.01,{ }^{\star} * \star P<0.001$.

from Sigma-Aldrich. The HRP-conjugated secondary antibodies were purchased from Dako (Cambridgeshire, UK) and incubated for $1 \mathrm{~h}$ at room temperature. All antibodies were used at a dilution of $1: 1000$. ECL (GE Healthcare, Uppsala, Sweden) was used and the signal was visualised by exposing to film. Where required, membranes were stripped with the Pierce Stripping Buffer (Thermo Scientific, Rockford, IL, USA) before being reprobed with a new antibody.

Correlation of miR-100 with tumour hypoxia in vivo. We have previously generated an in vivo hypoxia gene expression metagene signature in breast cancer; the median expression of this signature significantly correlated with tumour hypoxia (Winter et al, 2007; Buffa et al, 2010). MicroRNAs expression profiling has also been performed on these tumour samples (Buffa et al, 2011). The correlation of miR-100 expression to the hypoxia score of the tumours was assessed by Spearmann correlation.

Luciferase assays. Genomic region $(1.7 \mathrm{~kb})$ immediately upstream of the transcription start site of the human FGFR3 gene was cloned upstream of luciferase in the pGL3-basic backbone (Promega, Southhampton, UK). The Renilla luciferase vector pRL-TK (Promega) was used as a transfection control. Transfection of RT112 cells was performed using Fugene HD (Promega), according to the manufacturers' instructions. Cells were exposed to normoxia, $0.1 \% \mathrm{O}_{2}$ or normoxia and treated with $1 \mathrm{~mm}$ dimethyloxalylglycine (DMOG; Sigma-Aldrich) for $24 \mathrm{~h}$. Cells were lysed and assayed for luminescence with the Dual Luciferase Reporter Assay System (Promega).
Cellular proliferation assays. For two-dimensional (2-D) growth assays, cells were reverse transfected with the indicated reagents. The following day, cells were harvested and plated at a density of 1500 cells per well of a 96-well tissue culture plate. The cells were allowed to adhere for $24 \mathrm{~h}$ and then placed in either normoxia or $0.1 \% \mathrm{O}_{2}$ for further $48 \mathrm{~h}$. Cell viability was assessed with the sulphorhodamine assay (Houghton et al, 2007). For each transfection, data from five wells was taken.

For three-dimensional (3-D) growth assays, cells were reverse transfected with the indicated reagents. The following day, cells were harvested and plated at a density of 5000 cells per well of a 96-well ultra-low attachment plate (Corning, Amsterdam, The Netherlands), pelleted by centrifugation and allowed to grow as spheroids in normoxia for the indicated time. Spheroid volumes were calculated by extrapolation from their radii. For each transfection, data from 10 wells was taken.

Statistical analyses. Unless otherwise noted, all statistical analyses were performed with the unpaired Student's $t$-test.

\section{RESULTS}

Hypoxia induces FGFR3 expression in NMI bladder cancer cell lines. The expression of FGFR3 was first investigated in four bladder cell lines after exposure to hypoxia. Three cell lines, RT4, RT112 and 97-7, were derived from low-grade bladder cancer whereas the third cell line, T24, was derived from a grade- 3 highly malignant bladder cancer. The specificity of the antibody was 
A
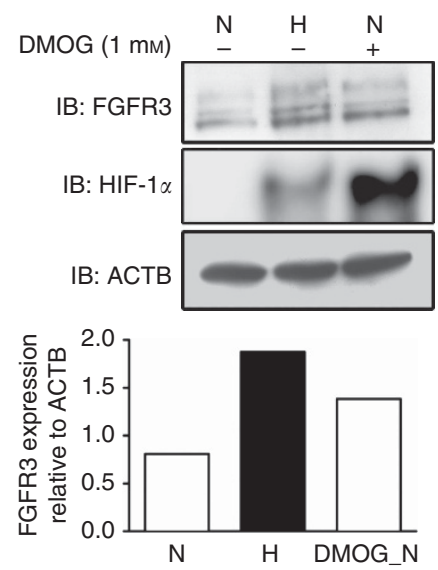

C

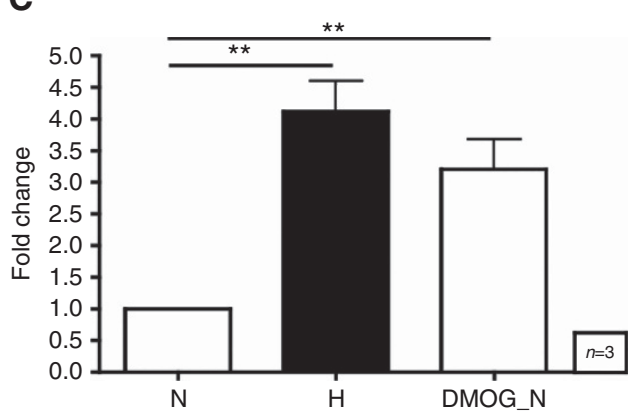

E
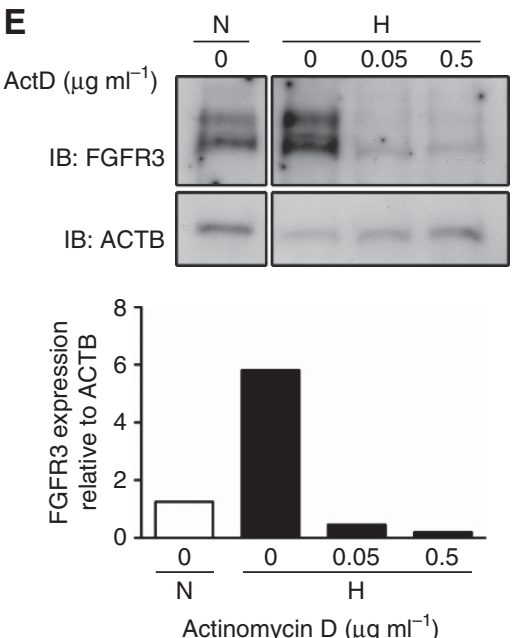

B

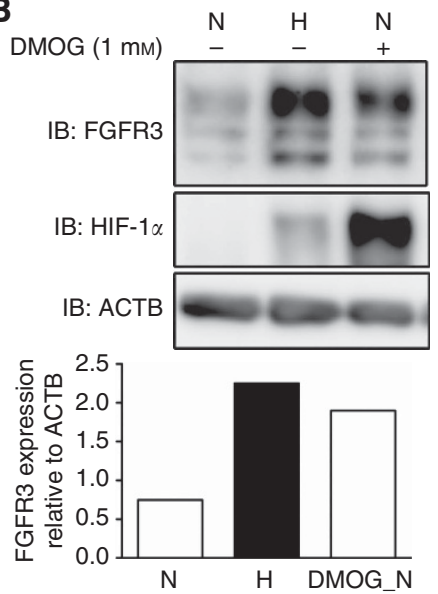

D
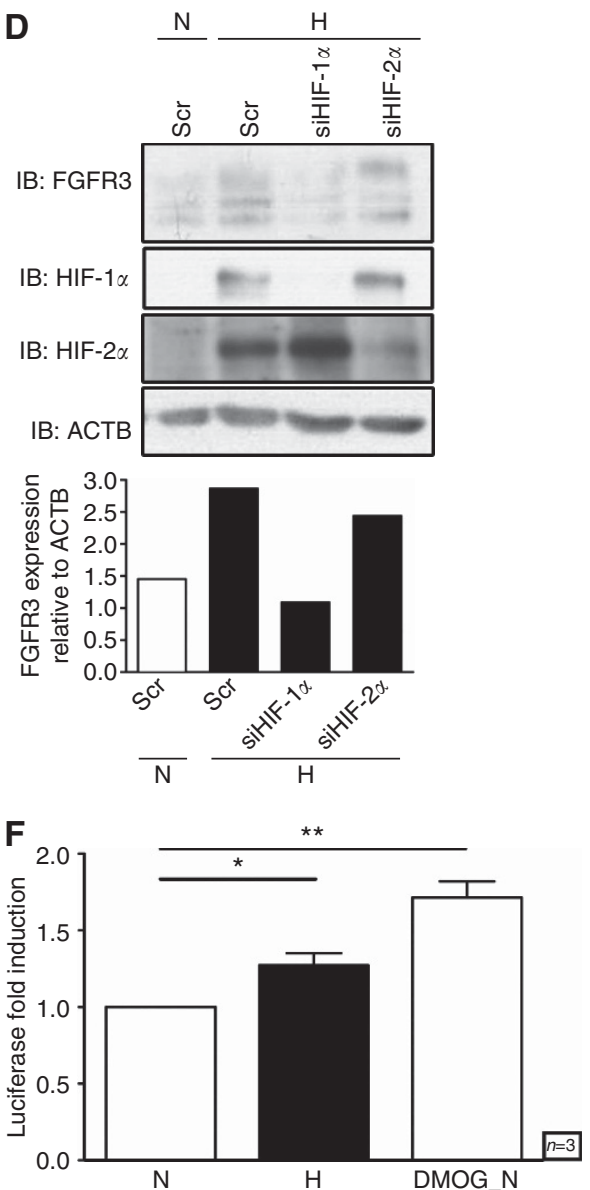

Figure 2. Mechanism of regulation of FGFR3 in hypoxia. (A) RT4 and (B) RT112 cells were cultured in normoxia $(\mathrm{N}), 0.1 \% \mathrm{O}_{2}(\mathrm{H})$ or in normoxia and treated with DMOG for $24 \mathrm{~h}$, and whole cell lysates were probed for FGFR3, HIF-1 $\alpha$ and ACTB. Quantification of representative western blots are shown. (C) Expression of FGFR3 mRNA in RT4 cells cultured in normoxia (N), $0.1 \% \mathrm{O}_{2}(\mathrm{H})$ or in normoxia and treated with DMOG for $24 \mathrm{~h}$. (D) Expression of FGFR3 protein in RT4 cells cultured in normoxia (N) or $0.1 \% \mathrm{O}_{2}(\mathrm{H})$ for $24 \mathrm{~h}$ after transfection with scramble (Scr) siRNA or siRNA against HIF-1 $\alpha$ or HIF-2 $\alpha$. Quantification of a representative western blot is shown. (E) Expression of FGFR3 protein in RT4 cells cultured in normoxia $(\mathrm{N})$ or $0.1 \% \mathrm{O}_{2}(\mathrm{H})$ and treated with the transcription inhibitor actinomycin $\mathrm{D}(\mathrm{ActD})$. Quantification of a representative western blot is shown. (F) Luciferase induction from an FGFR3 promoter reporter construct transfected into RT112 cells cultured for $24 \mathrm{~h}$ in normoxia (N), $0.1 \%$ O 2 $(\mathrm{H})$ or in normoxia and treated with $1 \mathrm{~mm} \mathrm{DMOG}$. (A and $\mathbf{D})$ data are representative of two independent experiments, (B and $\mathbf{E})$ data are representative of one experiment, ( $\mathbf{C}$ and $\mathbf{F}$ ). Data are mean and s.e.m. of the mean of three independent experiments. ${ }^{\star} P<0.05,{ }^{\star \star} P<0.01$, $\star * * P<0.001$

validated by performing western blot analyses after siRNA knockdown of FGFR3. The antibody was found to cross-react to a number of bands with molecular weights ranging from 120 to $150 \mathrm{kDa}$ (Supplementary Figure 1); these are most likely to be alternative spliced products of the FGFR3 transcript
(Martinez-Torrecuadrada et al, 2005), although post-translational modification is also possible. In both RT4 and RT112 cells, increased expression of FGFR3 protein was observed after exposure to $24 \mathrm{~h}$ in hypoxia (Figure 1A). In 97-7 cells, FGFR3 was expressed in both normoxic and hypoxic conditions but 
A

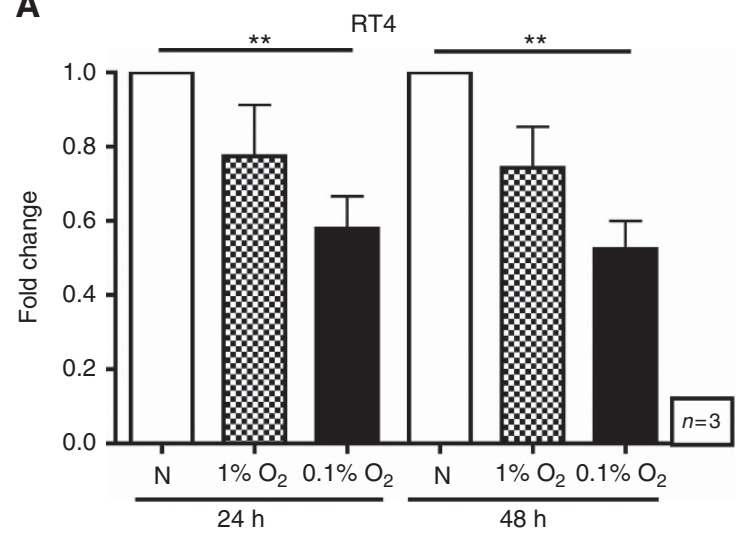

C

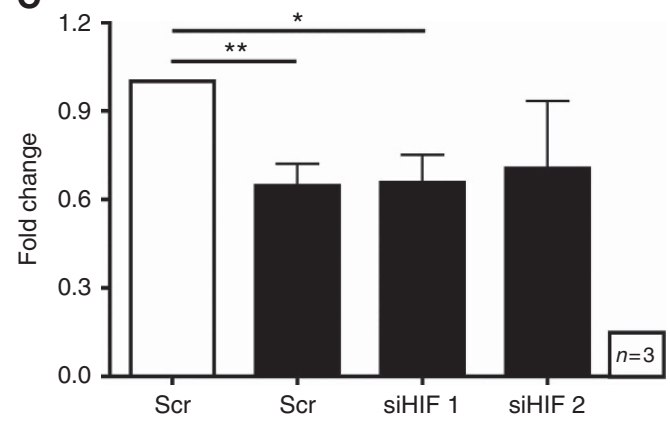

B

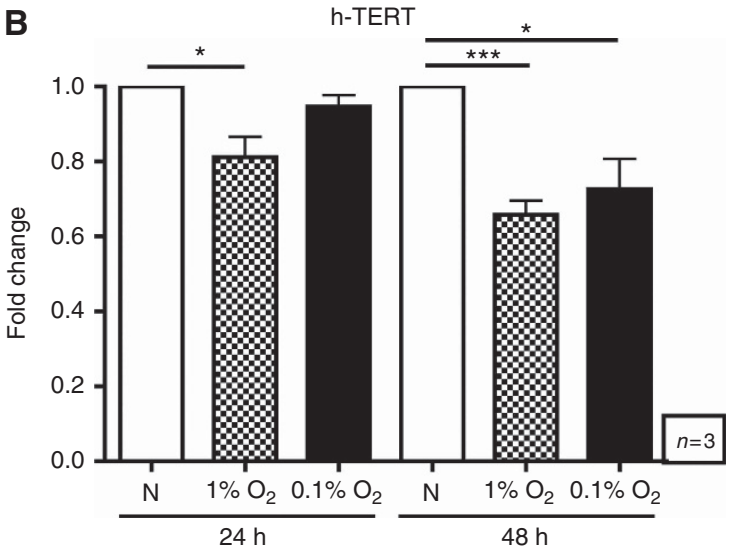

D

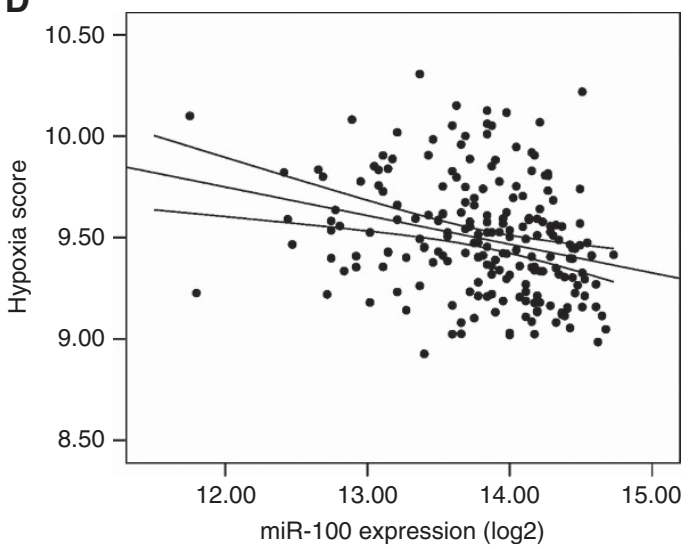

Figure 3. Relationship between miR-100 expression and hypoxia. ( $A$ and B) Expression of miR-100 in (A) RT4 and (B) h-TERT cells exposed to normoxia (white bars), $1 \% \mathrm{O}_{2}$ (hatched bars) or $0.1 \% \mathrm{O}_{2}$ (black bars) for the indicated time. (C) Expression of miR-100 in RT4 cells cultured in normoxia (white bar) or $0.1 \% \mathrm{O}_{2}$ (black bars) for $24 \mathrm{~h}$ after transfection with scramble (Scr) siRNA or siRNA against HIF-1 $\alpha$ or HIF-2 $\alpha$. (D) Correlation of miR-100 expression with the hypoxia score of 219 primary breast cancer samples. (A-C) Data are mean and s.e.m. of three independent experiments. ${ }^{*} P<0.05,{ }^{*} P<<0.01,{ }^{\star *} * P<0.001$.

further induction in hypoxia was not seen. In contrast, no expression of FGFR3 was detectable in T24 cells (Figure 1A). The induction of FGFR3 was also reflected at the mRNA level, where expression levels were induced in RT4 and RT112 but not in 97-7 cells at both 24 and $48 \mathrm{~h}$ (Figures 1B-D). The stabilisation of HIF by hypoxia was observed at the protein level (Figure 1A) and was also confirmed by the induction of the robust HIF- $1 \alpha$ target gene CAIX (Supplementary Figures 2A-D).

To further confirm the hypoxic induction of FGFR3 expression, RT4 and RT112 cells were treated with DMOG, a PHD inhibitor, in normoxia. Inhibiting PHD activity led to an increase in HIF protein levels in normoxia in both RT4 and RT112 cells (Figures $2 \mathrm{~A}$ and $\mathrm{B})$. Concomitant with this stabilisation of HIF, increased levels of FGFR3 protein were observed in both cell lines (Figures $2 \mathrm{~A}$ and $\mathrm{B}$ ). In RT4 cells, this increase at the protein level was accompanied by a concomitant increase in FGFR3 mRNA levels (Figure 2C). We next sought to determine the HIF dependence of FGFR3 expression. Knocking down HIF- $1 \alpha$ but not HIF- $2 \alpha$ expression significantly decreased FGFR3 mRNA (Supplementary Figure 3) and protein (Figure 2D) after exposure of RT4 cells to hypoxia. Furthermore, treatment of these cells with the transcription inhibitor actinomycin $\mathrm{D}$ also prevented the induction of FGFR3 protein levels in hypoxia (Figure 2E).

Using MatInspector (Cartharius et al, 2005) to search for putative HREs within the promoter region of FGFR3, two canonical RCGTG motifs were identified. However, these were not enriched when chromatin immunoprecipitations were performed with HIF- $1 \alpha$ (data not shown). Next, $1.7 \mathrm{~kb}$ of the FGFR3 gene upstream region was cloned into a luciferase plasmid to look at promoter activity. We were unsuccessful in transfecting RT4 cells with plasmid DNA. In RT112 cells, both exposure to hypoxia and treatment with $1 \mathrm{~mm}$ DMOG led to significant luciferase induction (Figure 2F), suggesting that this genomic region conferred hypoxia-responsive transcriptional activity.

miR-100 expression is suppressed by hypoxia. We have previously shown that FGFR3 is regulated by miR-100 expression in bladder cancer (Catto et al, 2009). To determine whether miR-100 may have a role in the hypoxic regulation of FGFR3 levels, miR-100 expression in RT4 cells after exposure to hypoxia was examined. Exposure to hypoxia for 24 and $48 \mathrm{~h}$ led to a significant decrease in miR-100 levels in RT4 (Figure 3A); miR-100 levels were unaffected by hypoxia in RT112, 97-7 and T24 cells (Supplementary Figure 4). To better understand the effect of hypoxia on miR-100 expression, its expression was also examined in the immortalised, but otherwise relatively normal, bladder urothelial line h-TERT; miR-100 levels were also suppressed by hypoxia in these cells (Figure 3B). To confirm that suppression of miR-100 was a specific outcome of hypoxia and not a general consequence of repression of the miRNA machinery, the expression of the robust hypoxia-induced miRNA, miR-210, was investigated. miR-210 was induced by hypoxia in all cell lines investigated (Blick et.al, manuscript in preparation).

The hypoxic suppression of miR-100 could not be reversed by knocking down either HIF- $1 \alpha$ or HIF- $2 \alpha$ (Figure $3 \mathrm{C}$ ). We have previously generated an in vivo hypoxia metagene signature that is 

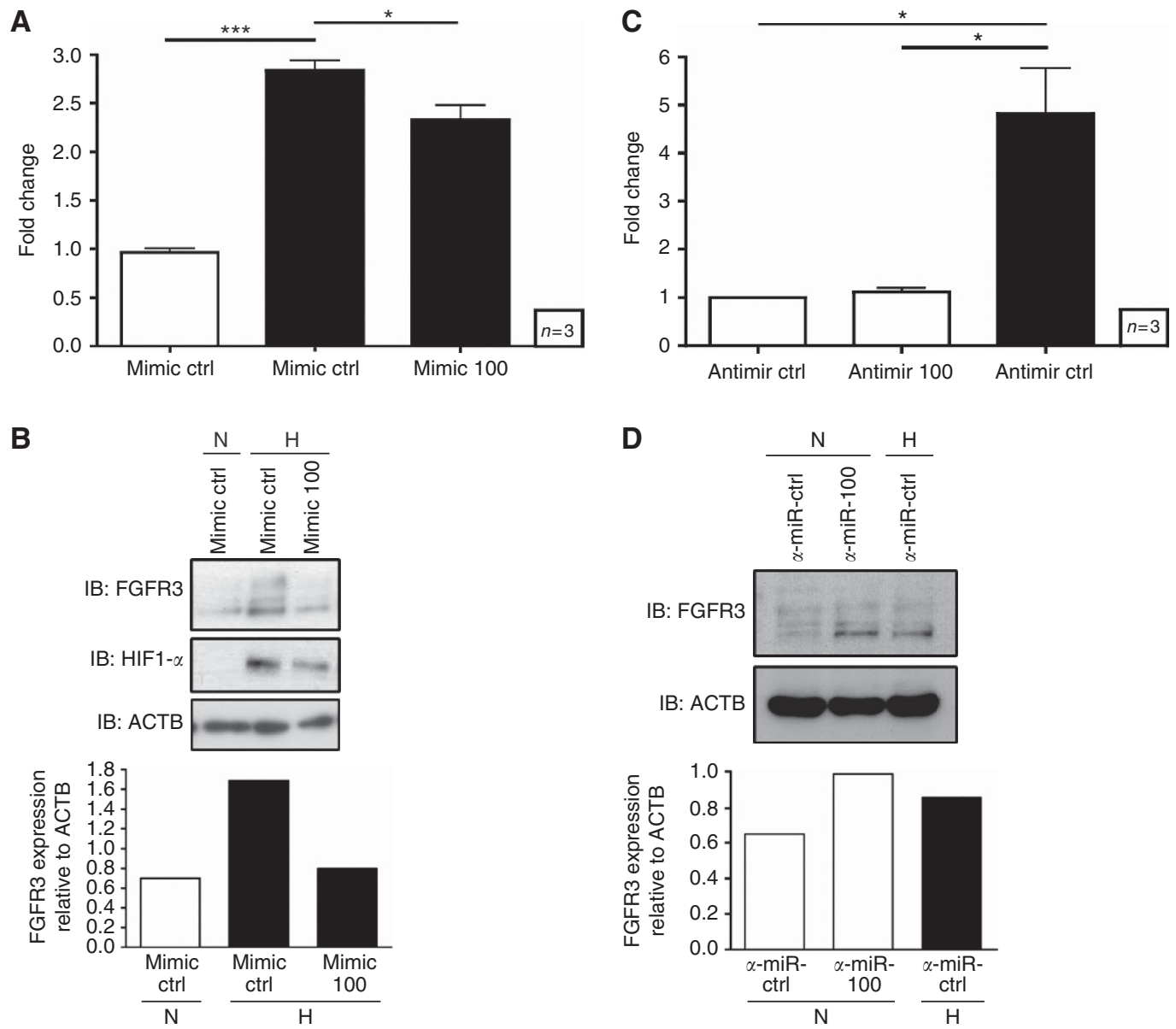

Figure 4. Regulation of FGFR3 by miR-100. (A) FGFR3 mRNA expression was examined in RT4 cells transfected with a miRNA control mimic or mimic-100 and exposed to normoxia (white bar) or $0.1 \% \mathrm{O}_{2}$ (black bars) for $24 \mathrm{~h}$. (B) FGFR3 protein expression was examined in RT4 cells transfected with a miRNA control mimic or mimic-100, and exposed to normoxia $(\mathrm{N})$ or $0.1 \% \mathrm{O}_{2}(\mathrm{H})$ for $24 \mathrm{~h}$. Quantification of a representative western blot is shown. (C) FGFR3 mRNA expression was examined in RT4 cells transfected with a control miRNA inhibitor (anti-miR-ctrl) or miR-100 inhibitor (anti-miR-100), and exposed to normoxia (white bars) or $0.1 \% \mathrm{O}_{2}$ (black bar) for $24 \mathrm{~h}$. (D) FGFR3 protein expression was examined in RT4 cells transfected with a control miRNA inhibitor (anti-miR-ctrl) or miR-100 inhibitor (anti-miR-100), and exposed to normoxia or $0.1 \% \mathrm{O}_{2}(\mathrm{H})$ for $24 \mathrm{~h}$. Quantification of a representative western blot is shown. (A and $\mathbf{C})$ Data are mean and s.e.m. of three independent experiments, (B and $\mathbf{D})$ data are representative of at least two independent experiments. ${ }^{\star} P<0.05,{ }^{*} P<0.01,{ }^{\star} * \star P<0.001$.

a robust indicator of tumour hypoxia (Winter et al, 2007; Buffa et al, 2010). To examine the relationship between miR-100 and hypoxia in vivo, we used our breast cancer tumour samples for which both miRNA and mRNA expression profile data is available (Buffa et al, 2011). In 219 breast cancer tumour samples, a significant inverse correlation between miR-100 expression and tumour hypoxia score was observed (Figure 3D).

It has previously been shown that the MYC oncogene suppresses transcription from the miR-100 locus (Cairo et al, 2010). As FGFR3 signalling can activate MYC (Zingone et al, 2010), we investigated whether FGFR3 signalling in hypoxia was responsible for reducing miR-100 levels. However, knocking down FGFR3 levels in RT4 did not affect miR-100 levels (data not shown).

miR-100 contributes to regulating FGFR3 levels in RT4 cells. The biological relevance of miR-100 on regulating FGFR3 expression in bladder cancer was investigated by perturbing miR-100 levels in RT4 cells by transfecting either mimic-100 in hypoxia (when miR-100 levels are low) or anti-miR-100 in normoxia (when miR-100 levels are high). The transfection of mimic-100 into RT4 cells modestly inhibited the hypoxic induction of FGFR3 mRNA (Figure 4A) and strongly inhibited FGFR3 expression at the protein level (Figure 4B). Importantly, although transfection of RT4 cells with anti-miR-100 in normoxia did not increase FGFR3 mRNA levels (Figure 4C), FGFR3 protein levels were increased after transfection of anti-miR-100 (Figure 4D). Thus, levels of miR-100 have a role in regulating FGFR3 protein levels in RT4 cells.

FGFR3 and miR-100 regulate cellular proliferation of RT4 cells. Activation of FGFR3 initiates signalling cascades in the cell primarily mediated by the MAPK and PI3K cascades. Therefore, the effects of FGFR3 and miR-100 on the activation of these downstream pathways was investigated. Activation of MAPK signalling ultimately leads to phosphorylation of the terminal kinase in the cascade, MAPK (p42/44 MAPK) whereas PI3K activation leads to the phosphorylation of PKB (Marshall et al, 2011). Transfection with siRNA against FGFR3 efficiently decreased FGFR3 protein levels (Supplementary Figure 1). FGFR3 knockdown reduced phosphorylation of $\operatorname{Ser}^{473}$ on PKB (Figure 5A) and the dual phosphorylation of $\mathrm{Thr}^{202} / \mathrm{Tyr}^{204}$ on MAPK (Figure 5B). This effect was more prominent under hypoxic conditions, where knockdown of FGFR3 led to an almost complete loss of PKB and ERK phosphorylation. In hypoxia, transfection of mimic-100 led to a modest decrease in phosphorylation of both PKB and MAPK (Figures 5A and B). Transfection of anti-miR-100 in normoxia did not appreciably alter phosphorylation of MAPK 
A
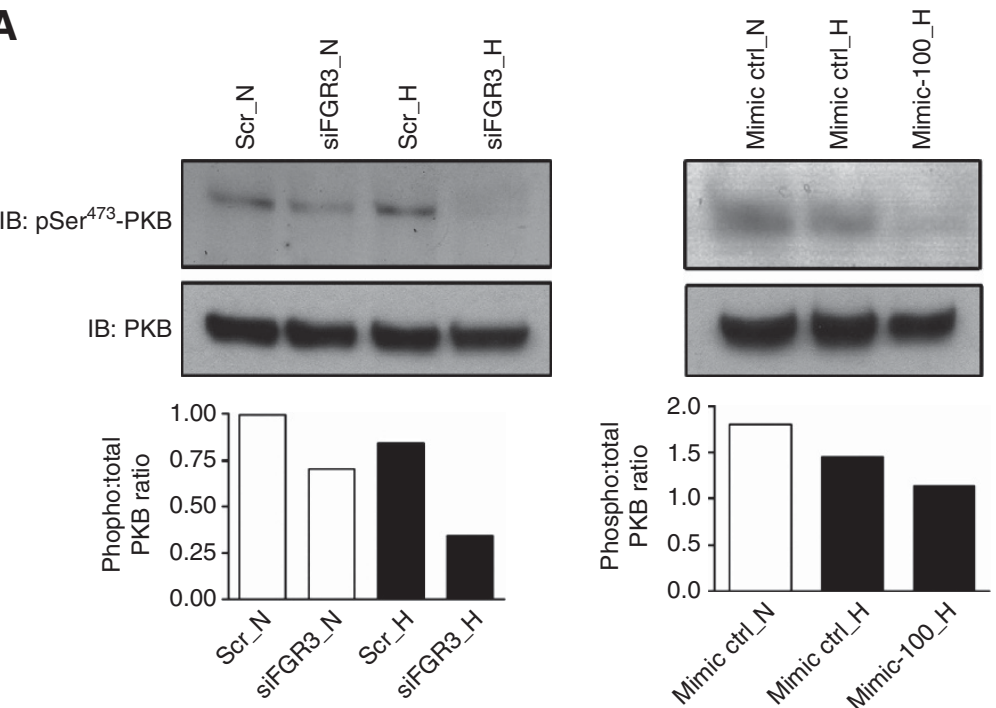

B
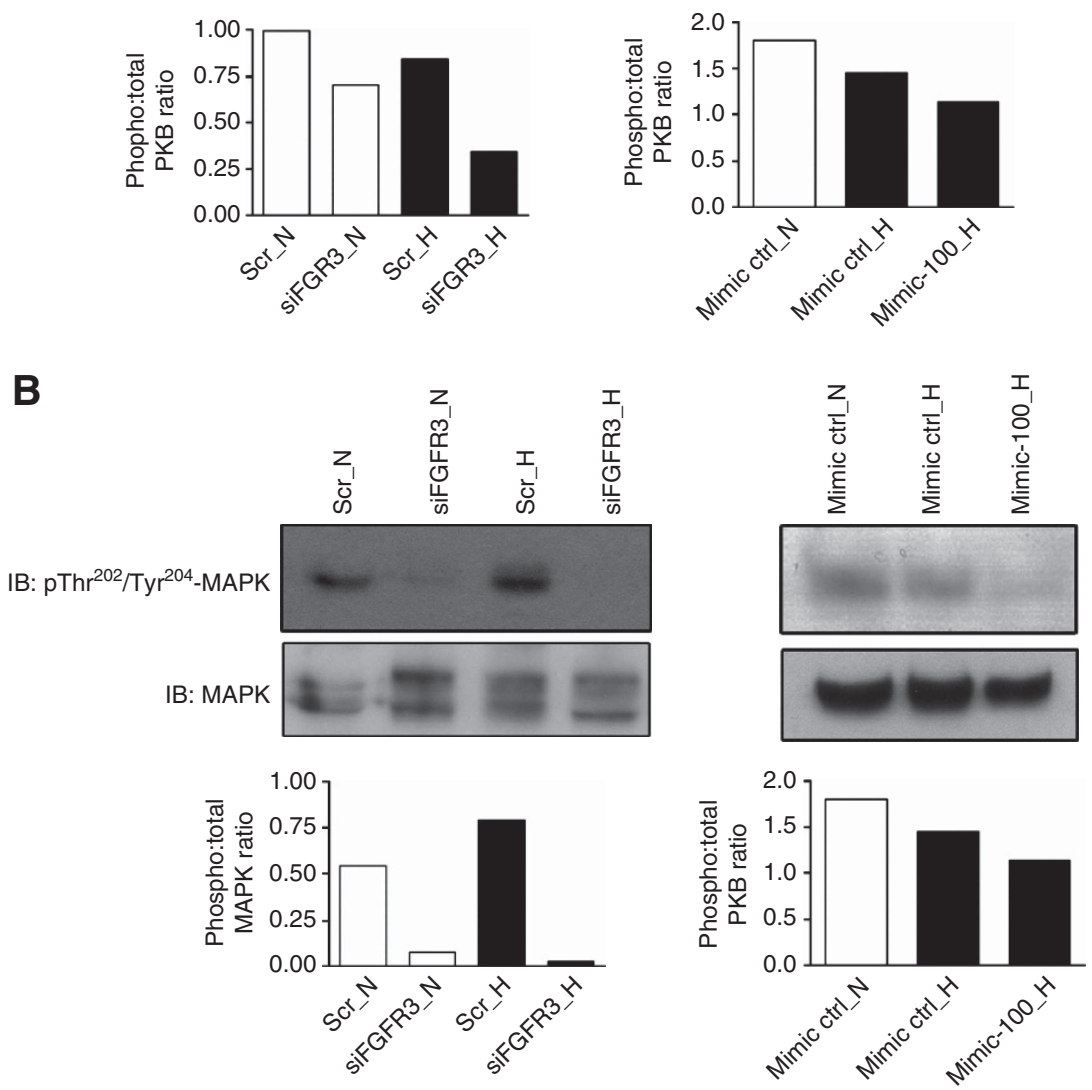

Figure 5. Regulation of PKB and MAPK activation by FGFR3 and miR-100. Whole cell lysates of RT4 cells transfected with scramble (Scr) or siFGFR3 siRNA (left panels) or miRNA control mimic or mimic-100 (right panels), and cultured in normoxia ( $\mathrm{N}$ ) or $0.1 \% \mathrm{O}_{2}(\mathrm{H})$ for $24 \mathrm{~h}$ were probed for (A) phospho-Ser ${ }^{473}$-PKB and total PKB, and (B) phospho-Thr ${ }^{202} / \mathrm{Tyr}^{204}-\mathrm{MAPK}$ and total MAPK. Quantification of representative western blots are shown. (A and $\mathbf{B})$ Data are representative of at least two independent experiments.

(Supplementary Figure 5). Thus, increased levels of FGFR3 have an important role in maintaining MAPK and $\mathrm{PKB}$ signalling in hypoxia.

It is well established that MAPK and PKB activation are potent mitogenic signals. Thus, the effects of miR-100 and FGFR3 on cell viability was investigated. In 2-D growth, knockdown of FGFR3 reduced proliferation of RT4 cells in normoxia and hypoxia (Figure 6A). In contrast, transfection of mimic-100 did not affect the 2-D growth (Figure 6B). To assess the effects of FGFR3 and miR-100 on 3-D growth, cells were grown as spheroids. FGFR3 knockdown significantly reduced the 3-D growth of RT4 cells (Figures 6C and E). In addition, transfection of mimic-100 also reduced spheroid volume of these cells (Figures $6 \mathrm{D}$ and F).

\section{DISCUSSION}

Hypoxia is an important aspect of tumour biology. It is known that in addition to its effects on metabolic reprogramming, hypoxia can lead to the activation of RTK signalling. HIF- $1 \alpha$ directly targets the C-MET receptor for transcriptional induction (Pennacchietti et al, 2003). Furthermore, HIF- $2 \alpha$ has been implicated in increased expression of the epidermal growth factor receptor by enhancing translation (Franovic et al, 2007; Wang and Schneider, 2010). In this study, we show for the first time that FGFR3 is induced by hypoxia in bladder cancer cell lines. Thus, tumour hypoxia may represent an additional mechanism for increased levels of FGFR3 in bladder cancer, and could be relevant in other tumours that have been shown to express FGFR3 including head, neck (Marshall et al, 2011) and liver cancer (Gauglhofer et al, 2011).

The upregulation of FGFR3 is dependent on transcription as mRNA levels were increased after exposure to both hypoxia and the hypoxia-mimetic DMOG, and treatment with the transcription inhibitor actinomycin D prevented the accumulation of FGFR3 protein after exposure to low oxygen. The increased expression of FGFR3 was primarily dependent on HIF- $1 \alpha$, as knockdown of this isoform of the $\alpha$-subunit had a stronger effect on suppressing FGFR3 levels in hypoxia. It should be noted that in these experiments, the knockdown of HIF- $2 \alpha$ was incomplete; thus, 

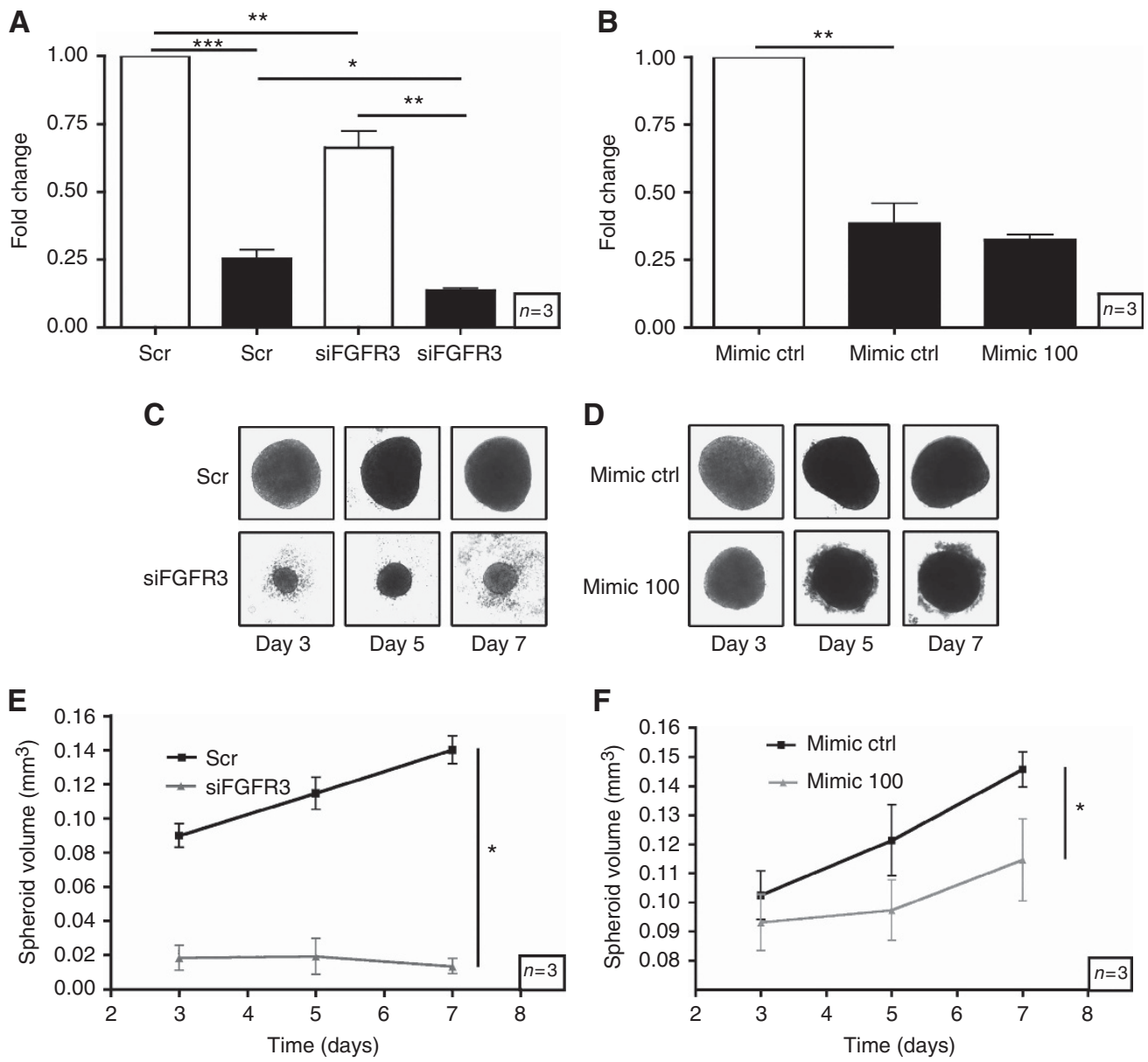

Figure 6. Regulation of RT4 proliferation by FGFR3 and miR-100. (A and B) Cell viability of RT4 cells in normoxia (white bars) or $0.1 \% \mathrm{O}_{2}$ (black bars) after transfection with (A) scramble (Scr) siRNA or siRNA against FGFR3 or (B) miRNA control mimic or mimic-100. (C and D) RT4 cells grown as spheroids over a time course after transfection with (C) scramble (Scr) siRNA or siRNA against FGFR3 or (D) miRNA control mimic or mimic-100. $(\mathbf{E}$ and $\mathbf{F})$ Quantification of $(\mathbf{C})$ and $(\mathbf{D})$, respectively. $(\mathbf{A}-\mathbf{F})$ Data are mean and s.e.m. of three independent experiments. ${ }^{\star} P<0.05$, ${ }^{\star \star} P<0.01$, $\star \star \star P<0.001$

although FGFR3 levels were unaffected after knockdown, HIF- $2 \alpha$ may still have a role in regulating its expression in hypoxia.

Although the FGFR3 promoter region did confer hypoxic transcriptional activity in a luciferase reporter assay, we have been unable to immunoprecipitate any HREs in this genomic region. Thus, either HREs exist in the region that we have not investigated or the hypoxic induction of FGFR3 is dependent on other transcription factors that act in syngergy/downstream of HIF. The coordinated regulation of FGFR3 expression by additional pathways warrants further investigation, as p73 and p63, members of the p53 family of transcription factors, have been shown to induce FGFR3 transcription (Sayan et al, 2010).

To further understand the potential mechanisms by which FGFR3 levels may be increased under hypoxia, the role of miR-100 was explored. We have previously shown that miR-100 can target FGFR3 and that the expression of these two molecules at the mRNA levels were negatively correlated in the bladder cancer (Catto et al, 2009). In both RT4 and h-TERT cells, hypoxia led to a suppression of miR-100 levels. We do not have a data set of matched miRNA and gene expression profiles available for bladder cancer. Thus, we interrogated our breast cancer cohort for which we have both miRNA (Buffa et al, 2011) and mRNA expresssion data, and in which we have previously employed a hypoxia scoring system to stratify tumours (Winter et al, 2007; Buffa et al, 2010). Importantly, in vivo, the expression of miR-100 was anti-correlated to tumour hypoxia in breast cancer, suggesting that the ability of hypoxia to decrease miR-100 levels extends to other tumour types.
The mechanism of downregulation of hypoxia-regulated genes, including miRNAs, is unclear. It is thought that the majority of genes downregulated by hypoxia are not direct targets of HIF (Mole et al, 2009). Indeed, the hypoxic suppression of miR-100 could not be reserved by knockdown of either HIF- $1 \alpha$ or HIF- $2 \alpha$. Although the majority of cellular responses to hypoxia are mediated by HIF, a number of HIF-independent events in hypoxia have been reported, including the induction of haeme oxygenase-1 in Chinese hamster ovary cells (Wiesener et al, 1998; Wood et al, 1998) and ICAM-1 in monocytes (Winning et al, 2010). It is likely that one of the other stress-response pathways is responsible for regulating the expression of a subset of genes under hypoxia (Koumenis and Wouters, 2006).

In RT4 cells, miR-100 expression contributes to the regulation of FGFR3 levels, as transfection of anti-miR-100 increased FGFR3 levels in normoxia and introduction of mimic-100 decreased FGFR3 levels in hypoxia. As the suppression of miR-100 was not dependent on the HIF- $\alpha$ subunits, yet hypoxic induction of FGFR3 could be reversed by HIF- $1 \alpha$ knockdown, we conclude that two parallel mechanisms operate to maintain increased FGFR3 levels in hypoxia. Of the two, the HIF- $1 \alpha$-dependent pathway is likely to have the central role, with the suppression of miR-100 serving to augment increased FGFR3 levels. The ability to circumvent miRNA-mediated regulation of gene expression can be advantageous to cells. Indeed, it has recently been shown that in glioblastoma, a duplication of chromosome $4 \mathrm{p} 16.3$ generates a FGFR3-TAAC3 fusion protein in which the $3^{\prime}$ UTR of FGFR3 is 
lost. The fusion protein is insensitive to regulation by the miR-99, a member of the miR-100 family, resulting in increased expression of the aberrant protein and enhanced tumour growth in xenografts models (Parker et al, 2013).

Functionally, FGFR3 and miR-100 are responsible for regulating cell proliferation of RT4 cells. Of note is the observation that knocking down FGFR3 expression in RT4 cells led to a dramatic decrease in cell viability in normoxia and hypoxia, concomitant with a decrease in the activation of PKB and MAPK signalling. Thus, even in cells expressing the FGFR3 without a point mutation, autocrine and/or paracrine signalling clearly have an indispensible role in cell viability. We found knockdown of FGFR3 had a more dramatic effect on reducing the phosphorylation of MAPK and PKB in cells exposed to hypoxia compared with their normoxic counterparts. This strongly suggests that increased levels of FGFR3 has a crucial role in maintaining the viability of RT4 cells exposed to hypoxia.

The role of miR-100 was found to be more subtle, with a decrease in cell viability observed in $3-\mathrm{D}$ cultures but not $2-\mathrm{D}$ growth. Thus, the role of miR-100 is more pronounced in stressful cellular conditions, when nutrient supply is perhaps more limiting and oxygen gradients are steeper. A single miRNA is likely to regulate the expression of multiple target genes, although the effect on each may be subtle (Selbach et al, 2008). Indeed, it has recently been reported that miR-100 can target mTOR (Nagaraja et al, 2010). Under more severe conditions of 3-D growth, miR-100 is likely to have a role in regulating cell proliferation by targeting additional pathways, such as mTOR, which has a key role during stress (Tickoo et al, 2011).

In summary, we have shown for the first time that hypoxic regulation of FGFR3 occurs at the transcriptional level but is also partly dependent on suppression of miR-100 expression. This represents a novel mechanism for regulating FGFR3 in bladder cancer that may provide an additional mechanism for increased expression of this growth-promoting pathway that could contribute to the pathogenesis of this disease. The link with hypoxia may explain the strong association with the papillary phenotype, where it has been shown that the luminal cells away from the vascular core are hypoxic. This may provide selection for upregulation of FGFR3 and maintenance of the papillary phenotype. FGFR3 overexpression may provide a positive effect by preventing progression to MI disease; the loss of this potentially protective mechanism requires additional studies. However, the clear effect of FGFR3 on signalling and growth under hypoxia also suggests a potential synthetic lethal approach, targeting the hypoxic cells away from the vascular core.

\section{ACKNOWLEDGEMENTS}

We are grateful to David Mole for his advice. This work is supported by grants from Cancer research UK and the NHIR Biomedical Research centre, Oxford. CB received grants from the Royal College of Surgeons of England, UCARE and the Urology Foundation. AR was funded by the Nuffield Dominion Trust.

\section{CONFLICT OF INTEREST}

The authors declare no conflict of interest.

\section{REFERENCES}

Brahimi-Horn MC, Pouyssegur J (2009) HIF at a glance. J Cell Sci 122(Pt 8): 1055-1057.

Buffa FM, Camps C, Winchester L, Snell CE, Gee HE, Sheldon H, Taylor M, Harris AL, Ragoussis J (2011) microRNA-associated progression pathways and potential therapeutic targets identified by integrated mRNA and microRNA expression profiling in breast cancer. Cancer Res 71(17): 5635-5645.

Buffa FM, Harris AL, West CM, Miller CJ (2010) Large meta-analysis of multiple cancers reveals a common, compact and highly prognostic hypoxia metagene. Br J Cancer 102(2): 428-435.

Cairo S, Wang Y, de Reynies A, Duroure K, Dahan J, Redon MJ, Fabre M, McClelland M, Wang XW, Croce CM, Buendia MA (2010) Stem cell-like micro-RNA signature driven by Myc in aggressive liver cancer. Proc Natl Acad Sci USA 107(47): 20471-20476.

Cartharius K, Frech K, Grote K, Klocke B, Haltmeier M, Klingenhoff A, Frisch M, Bayerlein M, Werner T (2005) MatInspector and beyond: promoter analysis based on transcription factor binding sites. Bioinformatics 21(13): 2933-2942.

Castillo-Martin M, Domingo-Domenech J, Karni-Schmidt O, Matos T, Cordon-Cardo C (2010) Molecular pathways of urothelial development and bladder tumorigenesis. Urol Oncol 28(4): 401-408.

Catto JW, Miah S, Owen HC, Bryant H, Myers K, Dudziec E, Larre S, Milo M, Rehman I, Rosario DJ, Di Martino E, Knowles MA, Meuth M, Harris AL, Hamdy FC (2009) Distinct microRNA alterations characterize high- and low-grade bladder cancer. Cancer Res 69(21): 8472-8481.

Chai CY, Chen WT, Hung WC, Kang WY, Huang YC, Su YC, Yang CH (2008) Hypoxia-inducible factor-1alpha expression correlates with focal macrophage infiltration, angiogenesis and unfavourable prognosis in urothelial carcinoma. J Clin Pathol 61(5): 658-664.

Dai H, Holm R, Kristensen GB, Abeler VM, Borresen-Dale AL, Helland A (2001) Fibroblast growth factor receptor 3 (FGFR3): analyses of the S249C mutation and protein expression in primary cervical carcinomas. Anal Cell Pathol 23(2): 45-49.

Foldynova-Trantirkova S, Wilcox WR, Krejci P (2012) Sixteen years and counting: the current understanding of fibroblast growth factor receptor 3 (FGFR3) signaling in skeletal dysplasias. Hum Mutat 33(1): 29-41.

Franovic A, Gunaratnam L, Smith K, Robert I, Patten D, Lee S (2007) Translational up-regulation of the EGFR by tumor hypoxia provides a nonmutational explanation for its overexpression in human cancer. Proc Natl Acad Sci USA 104(32): 13092-13097.

Gauglhofer C, Sagmeister S, Schrottmaier W, Fischer C, Rodgarkia-Dara C, Mohr T, Stattner S, Bichler C, Kandioler D, Wrba F, Schulte-Hermann R, Holzmann K, Grusch M, Marian B, Berger W, Grasl-Kraupp B (2011) Up-regulation of the fibroblast growth factor 8 subfamily in human hepatocellular carcinoma for cell survival and neoangiogenesis. Hepatology 53(3): 854-864.

Goebell PJ, Knowles MA (2010) Bladder cancer or bladder cancers? Genetically distinct malignant conditions of the urothelium. Urol Oncol 28(4): 409-428.

Gottardo F, Liu CG, Ferracin M, Calin GA, Fassan M, Bassi P, Sevignani C, Byrne D, Negrini M, Pagano F, Gomella LG, Croce CM, Baffa R (2007) Micro-RNA profiling in kidney and bladder cancers. Urol Oncol 25(5): 387-392.

Houghton P, Fang R, Techatanawat I, Steventon G, Hylands PJ, Lee CC (2007) The sulphorhodamine (SRB) assay and other approaches to testing plant extracts and derived compounds for activities related to reputed anticancer activity. Methods 42(4): 377-387.

Ioachim E, Michael M, Salmas M, Michael MM, Stavropoulos NE, MalamouMitsi V (2006) Hypoxia-inducible factors HIF-1alpha and HIF-2alpha expression in bladder cancer and their associations with other angiogenesis-related proteins. Urol Int 77(3): 255-263.

Koumenis C, Wouters BG (2006) "Translating" tumor hypoxia: unfolded protein response (UPR)-dependent and UPR-independent pathways. Mol Cancer Res 4(7): 423-436.

L'Hote CG, Knowles MA (2005) Cell responses to FGFR3 signalling: growth, differentiation and apoptosis. Exp Cell Res 304(2): 417-431.

Lamont FR, Tomlinson DC, Cooper PA, Shnyder SD, Chester JD, Knowles MA (2011) Small molecule FGF receptor inhibitors block FGFRdependent urothelial carcinoma growth in vitro and in vivo. $\mathrm{Br} J$ Cancer 104(1): 75-82.

Livak KJ, Schmittgen TD (2001) Analysis of relative gene expression data using real-time quantitative PCR and the $2(-$ Delta Delta $\mathrm{C}(\mathrm{T})$ ) method. Methods 25(4): 402-408.

Luis NM, Lopez-Knowles E, Real FX (2007) Molecular biology of bladder cancer. Clin Transl Oncol 9(1): 5-12.

Marshall ME, Hinz TK, Kono SA, Singleton KR, Bichon B, Ware KE, Marek L, Frederick BA, Raben D, Heasley LE (2011) Fibroblast growth factor 
receptors are components of autocrine signaling networks in head and neck squamous cell carcinoma cells. Clin Cancer Res 17(15): 5016-5025.

Martinez-Torrecuadrada J, Cifuentes G, Lopez-Serra P, Saenz P, Martinez A, Casal JI (2005) Targeting the extracellular domain of fibroblast growth factor receptor 3 with human single-chain $\mathrm{Fv}$ antibodies inhibits bladder carcinoma cell line proliferation. Clin Cancer Res 11(17): 6280-6290.

McConkey DJ, Lee S, Choi W, Tran M, Majewski T, Siefker-Radtke A, Dinney C, Czerniak B (2010) Molecular genetics of bladder cancer: emerging mechanisms of tumor initiation and progression. Urol Oncol 28(4): 429-440.

Mole DR, Blancher C, Copley RR, Pollard PJ, Gleadle JM, Ragoussis J, Ratcliffe PJ (2009) Genome-wide association of hypoxia-inducible factor (HIF)-1alpha and HIF-2alpha DNA binding with expression profiling of hypoxia-inducible transcripts. J Biol Chem 284(25): 16767-16775.

Nagaraja AK, Creighton CJ, Yu Z, Zhu H, Gunaratne PH, Reid JG, Olokpa E, Itamochi H, Ueno NT, Hawkins SM, Anderson ML, Matzuk MM (2010) A link between mir-100 and FRAP1/mTOR in clear cell ovarian cancer. Mol Endocrinol 24(2): 447-463.

Neely LA, Rieger-Christ KM, Neto BS, Eroshkin A, Garver J, Patel S, Phung NA, McLaughlin S, Libertino JA, Whitney D, Summerhayes IC (2010) A microRNA expression ratio defining the invasive phenotype in bladder tumors. Urol Oncol 28(1): 39-48.

Office for National Statistics, C. S. r. R. o. c. d. i., England. Series MB1 no. 37. 2009. National Statistics: London..

Ord JJ, Agrawal S, Thamboo TP, Roberts I, Campo L, Turley H, Han C, Fawcett DW, Kulkarni RP, Cranston D, Harris AL (2007) An investigation into the prognostic significance of necrosis and hypoxia in high grade and invasive bladder cancer. J Urol 178(2): 677-682.

Parker BC, Annala MJ, Cogdell DE, Granberg KJ, Sun Y, Ji P, Li X, Gumin J, Zheng H, Hu L, Yli-Harja O, Haapasalo H, Visakorpi T, Liu X, Liu CG, Sawaya R, Fuller GN, Chen K, Lang FL, Nykter M, Zhang W (2013) The tumorigenic FGFR3-TACC3 gene fusion escapes miR-99a regulation in glioblastoma. J Clin Invest 123(2): 855-865.

Pennacchietti S, Michieli P, Galluzzo M, Mazzone M, Giordano S, Comoglio PM (2003) Hypoxia promotes invasive growth by transcriptional activation of the met protooncogene. Cancer Cell 3(4): 347-361.

Pillai RS, Bhattacharyya SN, Filipowicz W (2007) Repression of protein synthesis by miRNAs: how many mechanisms? Trends Cell Biol 17(3): $118-126$.

Ploeg M, Aben KK, Kiemeney LA (2009) The present and future burden of urinary bladder cancer in the world. World J Urol 27(3): 289-293.

Pollard C, Smith SC, Theodorescu D (2010) Molecular genesis of non-muscleinvasive urothelial carcinoma (NMIUC). Expert Rev Mol Med 12: e10.

Sayan AE, D'Angelo B, Sayan BS, Tucci P, Cimini A, Ceru MP, Knight RA, Melino G (2010) p73 and p63 regulate the expression of fibroblast growth factor receptor 3. Biochem Biophys Res Commun 394(3): 824-828.

Selbach M, Schwanhausser B, Thierfelder N, Fang Z, Khanin R, Rajewsky N (2008) Widespread changes in protein synthesis induced by microRNAs. Nature 455(7209): 58-63.

Singh D, Chan JM, Zoppoli P, Niola F, Sullivan R, Castano A, Liu EM, Reichel J, Porrati P, Pellegatta S, Qiu K, Gao Z, Ceccarelli M, Riccardi R, Brat DJ, Guha A, Aldape K, Golfinos JG, Zagzag D, Mikkelsen T, Finocchiaro G, Lasorella A, Rabadan R, Iavarone A (2012) Transforming fusions of FGFR and TACC genes in human glioblastoma. Science 337(6099): 1231-1235.

Tickoo SK, Milowsky MI, Dhar N, Dudas ME, Gallagher DJ, Al-Ahmadie H, Gopalan A, Fine SW, Ishill N, Bajorin DF, Reuter VE (2011) Hypoxiainducible factor and mammalian target of rapamycin pathway markers in urothelial carcinoma of the bladder: possible therapeutic implications. BJU Int 107(5): 844-849.

Tomlinson DC, Baldo O, Harnden P, Knowles MA (2007) FGFR3 protein expression and its relationship to mutation status and prognostic variables in bladder cancer. J Pathol 213(1): 91-98.

Toydemir RM, Brassington AE, Bayrak-Toydemir P, Krakowiak PA, Jorde LB, Whitby FG, Longo N, Viskochil DH, Carey JC, Bamshad MJ (2006) A novel mutation in FGFR3 causes camptodactyly, tall stature, and hearing loss (CATSHL) syndrome. Am J Hum Genet 79(5): 935-941.

Turner KJ, Crew JP, Wykoff CC, Watson PH, Poulsom R, Pastorek J, Ratcliffe PJ, Cranston D, Harris AL (2002) The hypoxia-inducible genes VEGF and CA9 are differentially regulated in superficial vs invasive bladder cancer. Br J Cancer 86(8): 1276-1282.

Wang X, Schneider A (2010) HIF-2alpha-mediated activation of the epidermal growth factor receptor potentiates head and neck cancer cell migration in response to hypoxia. Carcinogenesis 31(7): 1202-1210.

Wiesener MS, Turley H, Allen WE, Willam C, Eckardt KU, Talks KL, Wood SM, Gatter KC, Harris AL, Pugh CW, Ratcliffe PJ, Maxwell PH (1998) Induction of endothelial PAS domain protein-1 by hypoxia: characterization and comparison with hypoxia-inducible factor-1alpha. Blood 92(7): 2260-2268.

Winning S, Splettstoesser F, Fandrey J, Frede S (2010) Acute hypoxia induces HIF-independent monocyte adhesion to endothelial cells through increased intercellular adhesion molecule-1 expression: the role of hypoxic inhibition of prolyl hydroxylase activity for the induction of NF-kappa B. J Immunol 185(3): 1786-1793.

Winter SC, Buffa FM, Silva P, Miller C, Valentine HR, Turley H, Shah KA, Cox GJ, Corbridge RJ, Homer JJ, Musgrove B, Slevin N, Sloan P, Price P, West CM, Harris AL (2007) Relation of a hypoxia metagene derived from head and neck cancer to prognosis of multiple cancers. Cancer Res 67(7): 3441-3449.

Wood SM, Wiesener MS, Yeates KM, Okada N, Pugh CW, Maxwell PH, Ratcliffe PJ (1998) Selection and analysis of a mutant cell line defective in the hypoxia-inducible factor-1 alpha-subunit (HIF-1alpha).

Characterization of hif-1alpha-dependent and -independent hypoxiainducible gene expression. J Biol Chem 273(14): 8360-8368.

Wu XR (2005) Urothelial tumorigenesis: a tale of divergent pathways. Nat Rev Cancer 5(9): 713-725.

Zingone A, Cultraro CM, Shin DM, Bean CM, Morse 3rd HC, Janz S, Kuehl WM (2010) Ectopic expression of wild-type FGFR3 cooperates with MYC to accelerate development of B-cell lineage neoplasms. Leukemia 24(6): 1171-1178.

This work is published under the standard license to publish agreement. After 12 months the work will become freely available and the license terms will switch to a Creative Commons AttributionNonCommercial-Share Alike 3.0 Unported License.

Supplementary Information accompanies this paper on British Journal of Cancer website (http://www.nature.com/bjc) 